\title{
Comparison of Rainfall Forecasting in Simple Moving Average (SMA) and Weighted Moving Average (WMA) Methods (Case Study at Village of Gampong Blang Bintang, Big Aceh District-Sumatera-Indonesia
}

\author{
Siti Rusdiana $^{I^{*}}$, Syarifah Meurah Yuni ${ }^{1}$, Delia Khairunnisa ${ }^{I}$ \\ ${ }^{1}$ Department of Mathematics, Universitas Syiah Kuala, Banda Aceh, 23111, Indonesia
}

\begin{abstract}
The changing climate causes rainfall to vary from period to period. This change has an impact on society, especially in agriculture such as crop failure. This study aims to predict rainfall in 2018 and 2019 with the Simple Moving Average (SMA) method and the Weighted Moving Average (WMA) method. Based on 2004-2018 data, the dry season occurs in February-October and the rainy season in November-January. The level of validation of forecasters in 2018 according to each the SMA method and the WMA method were $43.43 \%$ and $40.69 \%$, respectively. Both of these methods are low and reasonable or acceptable. Based on the SMA method, the division of the dry season in 2019 is estimated in February-October while the distribution of the rainy season in the same year is in December-January. Based on the WMA Method that the distribution of the dry season is estimated in February-April, June-September and the rainy season in October-January and May.
\end{abstract}

Keyword:Rainfall, forecasting, Simple Moving Average (SMA), Weighted Moving Average (WMA)

Abstrak. Perubahan iklim menyebabkan curah hujan bervariasi dari periode ke periode. Perubahan ini memiliki dampak pada lingkungan, terutama pada agrikultur seperti kegagalan hasil panen. Pembelajaran ini bertujuan untuk memprediksi curah hujan pada tahun 2018 dan 2019 dengan metode Simple Moving Average (SMA) dan metode Weighted Moving Average (WMA). Berdasarkan data tahun 2004-2018, musim kemarau muncul pada bulan Februari-Oktober dan musim hujan pada bulan November-Januari. Tingkat validasi dari peramalan pada tahun 2018 berdasarkan metode SMA dan WMA berturutturut adalah 43,43\% dan 40,69\%. Kedua metode ini rendah dan masuk akal atau dapat diterima. Berdasarkan metode SMA, pembagian musim kemarau pada tahun 2019 diperkirakan pada bulan Februari-Oktober sementara distribusi dari musim hujan pada tahun yang sama pada bulan Desember-Januari. Berdasarkan metode WMA, distribusi pada musim kemarau diperkirakan pada bulan Februari-April, Juni-September dan musim hujan pada bulan Oktober-Januari dan Mei.

Kata Kunci:Curah hujan, permalan, simple moving average (SMA), wieighted moving average (WMA)

Received 7 December 2019| Revised 7 January 2020 | Accepted 12 February 2020

*Corresponding author at: Department of Mathematics, Universitas Syiah Kuala, Banda Aceh, 23111, Indonesia

E-mail address: siti.rusdiana@unsyiah.ac.id 


\section{Introduction}

Climate is a condition where temperature, weather and atmosphere in an area over a long period of time. According to [1]. Besides climate is a condition that occurs on the surface of the earth which is influenced by air conditions against pressure and temperature. Climate change in Indonesia from time to time is increasingly changing where some periods ago the rainfall was very high in a particular month but in the current period the rainfall is decreasing. This change can affect community activities in farming. To reduce the percentage of crop failure, adjustments must be made. This adjustment can be done by forecasting. Forecasting of rainfall that will occur from the previous period to the next period. Forecasting is an attempt to predict a future event by looking at the situation in the past. The other reserach to predicted rainfall and discharge by using Vector Autoregressive (VAR), rainfall and discharge data in 2008-2015 is used to predicted rainfall for the next five years 2016-2020 has done by [2]. The essence of forecasting is the estimation of future events based on patterns in the past [3]. This study adds one method of time series, the WMA method. Both of these methods were chosen because they have a small number of decision variables. Where this variable can be used for forecasting the next year. Researchers used the SMA method and the WMA method for forecasting rainfall in 2019 specifically in one village in Big Aceh District.

\section{Research Methodology}

\subsection{The Rainfall}

The beginning of the season is applied from the amount of rainfall dasari $\geq 50 \mathrm{~mm}$ and is followed by at least two subsequent days. (Giarno et al, 2012)

The division of seasons based on rainfall in one month is as follows:

- rainfall $\geq 150 \mathrm{~mm}$ for the rainy season

- rainfall $<150 \mathrm{~mm}$ for the dry season

\subsection{Simple Moving Average (SMA)}

According to [4], the Simple Moving Average (SMA) method was discovered by G. U. Yule in 1909. This method is said to be a moving average because the value of forecasting will change once the latest data is obtained by calculation through this formula:

where:

$$
S_{i, j}=\frac{1}{n} \sum_{k=1}^{n} X_{i, j-k}
$$

$S_{i, j} \quad:$ the forecasting method of SMA in month $i$ th year $j$ th

$X_{i, j-k}:$ the data of the months of $i$ th year $j-k$ th

$n \quad$ : the period of forecasting 


\subsection{Weighted Moving Average (WMA)}

According to [5], the WMA method is a method of forecasting that is done by giving weight to each period. Calculations using the WMA method require weighting where each data is given a different weight. This weighting is given sequentially based on the latest data where the latest data or the most recent data is given the greatest weight because the latest data is the most relevant data for forecasting. According to [6]. The selection of weight values for forecasting is chosen based on the number of periods (years) used with the assumption that forecasting can only be used for the following year.

where:

$$
W_{i, j}=\frac{\sum_{k=1}^{n} X_{i, j-k} \times w_{j-k}}{\sum_{k=1}^{n} w_{j-k}}
$$

$W_{i, j} \quad$ : the forecasting method of WMA in month $i$ th year $j$ th

$w_{j-k}:$ weight in the years of $j-k$ th

$X_{i, j-k}$ : the data of the months of $i$ th year $j-k$ th

$n \quad$ : the period of forecasting

\subsection{MAPE (Mean Absolute Percent)}

where :

$$
M A P E=\frac{1}{n}\left[\sum_{i=1}^{n}\left|\frac{A_{i}-F_{i}}{A_{i}}\right| \times 100 \%\right]
$$

$A_{i} \quad:$

$F_{i} \quad:$ actual demand in period $i$ th

$\frac{A_{i}-F_{i}}{A_{i}}:$ the error value

$n \quad$ : number of forecasting periods involved

\section{Results and Discussion}

\subsection{Forecasting by The SMA Method in 2018}

Table 1 Hypothesis Table Data for Multifactorial Frequency Analysis

\begin{tabular}{ccc}
\hline Month & Forecasting 2018 $(\mathbf{m m})$ & Devision of Forecasting 2018 (R=rain, D=dry) \\
\hline January & 181,49 & $\mathrm{R}$ \\
February & 102,21 & $\mathrm{D}$ \\
March & 144,54 & $\mathrm{D}$ \\
April & 132,92 & $\mathrm{D}$ \\
May & 118,914 & $\mathrm{D}$ \\
June & 76,686 & $\mathrm{D}$ \\
July & 66,4 & $\mathrm{D}$ \\
August & 89,479 & $\mathrm{D}$ \\
September & 107,98 & $\mathrm{D}$ \\
October & 136,86 & $\mathrm{D}$ \\
November & 292,86 & $\mathrm{R}$ \\
December & 225,13 & $\mathrm{R}$ \\
\hline
\end{tabular}


The rainy season is predicted to occur in November-January and the dry season in FebruaryOctober.

\subsection{Forecasting by The WMA Method in 2018}

Assuming the weight value annually is shown in table 2 and will be used to find the solution for forecasting the WMA method.

Table 2 The Weight of The Year 2004-2018

\begin{tabular}{cccc}
\hline Year & Weight $(w)$ & Year & Weight $(w)$ \\
\hline 2004 & 1 & 2011 & 8 \\
2005 & 2 & 2012 & 9 \\
2006 & 3 & 2013 & 10 \\
2007 & 4 & 2014 & 11 \\
2008 & 5 & 2015 & 12 \\
2009 & 6 & 2016 & 13 \\
2010 & 7 & 2017 & 14 \\
& & 2018 & 15 \\
\hline
\end{tabular}

Table 3 The Result of Forecasting of WMA Method Year 2018

\begin{tabular}{ccc}
\hline Month & Forecasting 2018 $(\mathbf{m m})$ & Devision of Forecasting 2018 (R=Rain, D=Dry) \\
\hline January & 201,03 & $\mathrm{R}$ \\
February & 100,457 & $\mathrm{D}$ \\
March & 136,845 & $\mathrm{D}$ \\
April & 130,861 & $\mathrm{D}$ \\
May & 118,274 & $\mathrm{D}$ \\
June & 71,8724 & $\mathrm{D}$ \\
July & 63,6105 & $\mathrm{D}$ \\
August & 108,774 & $\mathrm{D}$ \\
September & 126,392 & $\mathrm{D}$ \\
October & 175,78 & $\mathrm{H}$ \\
November & 324,312 & $\mathrm{R}$ \\
December & 262,714 & $\mathrm{R}$ \\
\hline
\end{tabular}

The rainy season is predicted to occur in October-January and the dry season in FebruaryOctober

\subsection{The Accuracy of The Result of MAPE Method}

Table 4 The Accuracy of The Results of Rainfall Forecast in 2018 for each of The SMA and The WMA Method

\begin{tabular}{ccc}
\hline Month & Error SMA & Error WMA \\
\hline January & 0,2818 & 0,2045 \\
February & 0,5548 & 0,5625 \\
March & 0,8796 & 0,7795 \\
April & 0,4925 & 0,5003 \\
May & 0,7042 & 0,7058 \\
June & 0,0054 & 0,0678 \\
July & 0,1873 & 0,2214 \\
August & 0,0591 & 0,1438 \\
September & 0,4508 & 0,3571 \\
October & 0,5542 & 0,4274 \\
November & 0,4937 & 0,4393 \\
December & 0,5487 & 0,4733 \\
\hline
\end{tabular}




$$
\begin{aligned}
\text { MAPE SMA } & =\frac{1}{n}\left[\sum_{i=1}^{n}\left|\frac{A_{i}-F_{i}}{A_{i}}\right| \times 100 \%\right] \\
& =\frac{1}{12}\left[\left(\left|\frac{A_{1}-F_{1}}{A_{1}}\right|+\left|\frac{A_{2}-F_{2}}{A_{2}}\right|+\cdots+\left|\frac{A_{12}-F_{12}}{A_{12}}\right|\right) \times 100 \%\right] \\
& =\frac{1}{12}[5,2119 \times 100 \%] \\
\text { MAPE of SMA } & =43,43 \% \\
\text { MAPE WMA } & =\frac{1}{n}\left[\sum_{i=1}^{n}\left|\frac{A_{i}-F_{i}}{A_{i}}\right| \times 100 \%\right] \\
& =\frac{1}{12}\left[\left(\left|\frac{A_{1}-F_{1}}{A_{1}}\right|+\left|\frac{A_{2}-F_{2}}{A_{2}}\right|+\cdots+\left|\frac{A_{12}-F_{12}}{A_{12}}\right|\right) \times 100 \%\right] \\
& =\frac{1}{12}[4,8827 \times 100 \%] \\
\text { MAPE of WMA } & =40,69 \%
\end{aligned}
$$

\subsection{Forecasting by The SMA Method in 2019}

Table 5 The Result of Forecasting SMA Method Year 2019

\begin{tabular}{ccc}
\hline Month & Forecasting 2019 $(\mathbf{m m})$ & Devision of forecasting 2019 (R=Rain, D=Dry) \\
\hline January & 186,233 & $\mathrm{R}$ \\
February & 110,7 & $\mathrm{D}$ \\
March & 140,033 & $\mathrm{D}$ \\
April & 141,473 & $\mathrm{D}$ \\
May & 137,787 & $\mathrm{D}$ \\
June & 76,713 & $\mathrm{D}$ \\
July & 67,42 & $\mathrm{D}$ \\
August & 89,853 & $\mathrm{D}$ \\
September & 113,887 & $\mathrm{D}$ \\
October & 148,2 & $\mathrm{D}$ \\
November & 311,873 & $\mathrm{R}$ \\
December & 243,373 & $\mathrm{R}$ \\
\hline
\end{tabular}

The Forecasting results for the SMA method shown in table 5 can be concluded that the rainy season is expected to occur in November-January and the dry season is expected to occur in February-October.

\subsection{Forecasting by The WMA Method in 2019}

Table 6 The Result of Forecasting WMA Method Year 2019

\begin{tabular}{ccc}
\hline Month & Forecasting 2019 $(\mathbf{m m})$ & Devision of forecasting 2019 (R=Rain, D=Dry) \\
\hline January & 207,488 & $\mathrm{R}$ \\
February & 116,6 & $\mathrm{D}$ \\
March & 130,2267 & $\mathrm{D}$ \\
April & 147,1533 & $\mathrm{D}$ \\
May & 153,74 & $\mathrm{R}$ \\
June & 72,52583 & $\mathrm{D}$ \\
July & 65,87167 & $\mathrm{D}$ \\
August & 107,065 & $\mathrm{D}$ \\
\hline
\end{tabular}


Table 7 The Result of Forecasting WMA Method Year 2019

\begin{tabular}{ccc}
\hline Month & Forecasting 2019 $(\mathbf{m m})$ & Devision of forecasting 2019 (R=Rain, D=Dry) \\
\hline September & 135,1683 & $\mathrm{D}$ \\
October & 192,1825 & $\mathrm{R}$ \\
November & 357,0233 & $\mathrm{R}$ \\
December & 292,225 & $\mathrm{R}$ \\
\hline
\end{tabular}

The Forecasting results for the WMA method shown in table 6 can be seen that the rainy season is expected to occur in October-January, May and the dry season is expected to occur in February-April, June-September.

3.6. The Comparative Analysis of Forecasting Results using The SMA Method and The WMA Method in 2019

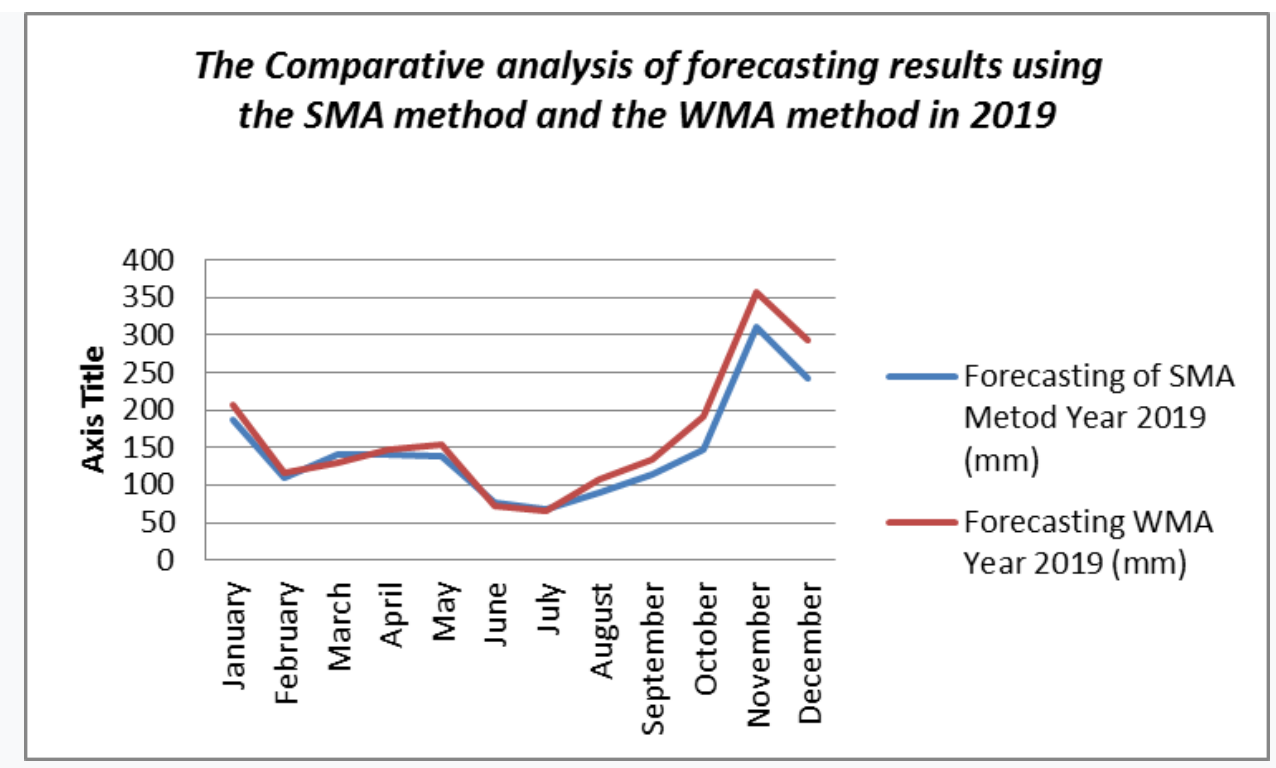

Figure 1 The Chart of Forecasting Year 2019

In Figure 1 it can be seen that the difference in rainfall forecasting through the use of the SMA method and the WMA method is found in May and October where in the SMA method the month is included in the dry season. In the WMA method these months are included in the rainy season.

\section{Conclusion}

Based on the results and discussion of rainfall forecasting using the SMA method and the WMA method in the Blang Bintang sub-district, it can be concluded that:

1. Based on 2004-2018 data, the dry season occurs in February-October and the rainy season in November-January. The level of validation of forecasters in 2018 according to each the SMA method and the WMA method were $43.43 \%$ and $40.69 \%$, respectively. Both of these methods are low and reasonable or acceptable. Based on the SMA method, the division of the dry season in 2019 is estimated in February-October while the distribution of the rainy season in the same year is in December-January. Based on the WMA Method that the 
distribution of the dry season is estimated in February-April, June-September and the rainy season in October-January and May.

2. The Forecasting rainfall in 2018 through calculations using the SMA method the rainy season occurs in November-January and the dry season in February-October and forecasting the WMA method, the rainy season occurs in October-January and the dry season in February-September.

3. The division of seasons is based on actual data of 2018, the rainy season takes place in September-February, April-May and the dry season in March, June-August.

In accordance with the analysis based on the results of calculations in 2019 using the SMA method, it is estimated that the rainy season will occur in November-January and the dry season in February-October. Estimates using the WMA method for the rainy season are OctoberJanuary, May and the dry season in February-April, June-November.

\section{REFERENCES}

[1] R. J. Kodoatie and R. Sjarief, Tata Ruang Air, Yogyakarta: Andi Publisher, 2010.

[2] I. Ramli, S. Rusdiana, H. Basri, A. A. Munawar and V. Azelia, "Predicted Rainfall and Discharge using Vector Autoregressive Models in Water Resources Management in the High Hill Takengon," IOP Conf. Ser. Earth Environ. Sci., vol. 273, p. 012009, Jul. 2019.

[3] H. Prasetya and F. Lukiastuti, Manajemen Operasi. Yogyakarta: MedPress, 2009.

[4] T. McClellan and S. McClellan, "History and Background Who First Came Up With Moving Average," www.mcoscillator.com, 2019. [Online]. Available: //www.mcoscillator.com/learning_center/kb/market_history_and_background/who_first_ came_up_with_moving_averages/

[5] J. Heizer, Operations Management (Subscription), New Jersey: Person, 2011.

[6] A. A. Gofur and U. D. Widianti, "Sistem Peramalan Untuk Pengadaan Material Unit Injection di PT.XYZ.,” J. Ilm. Komput. dan Inform., vol. 2, no. 2, 2013. 